\title{
PADA HUBUNGAN ANTARA PERSEPSI, JENIS KELAMIN, STATUS TEMPAT TINGGAL, STATUS ORANG TUA DENGAN PERILAKU PENYALAHGUNAAAN NAPZA PADA KELAS XI DI SMK DARUL HUDA SIDOARJO
}

\author{
Erika Martining Wardani ${ }^{1}$, Yurike Septianingrum ${ }^{2}$ \\ 1,2Prodi S1 Keperawatan Fakultas Keperawatan, Universitas Nahdlatul Ulama Surabaya \\ e-mail: : erika@unusa.ac.id ${ }^{1}$
}

\begin{abstract}
Adolescence signify of transition from childhood to adulthood is easy to having psychology and behavior problems, such as learning difficulty, anxiety, and drug addiction. School children as vulnerable group in drugs abuse behavior. The impact of drug abuse particularly alternately needle use get risk infection disease such as hepatitis $B, C$, and HIV. The objective of this research to examines the correlation between perception, sex, domicile status, parent status with drugs abuse behavior. This study used cross sectional analytical design with simple random sampling technique. Population of the research are students of 155 individuals, sample with 50 respondents. Data analysis employed chi square test. The result indicates that $83,7 \%$ having drugs abuse behavior with statistic test found there are no correlation between perception ( value $=0,826)$ and drugs abuse behavior, and found correlation between sex ( value $=0,001)$, domicile status relationship ( value $=0,001)$, parent status relationship ( value $=0,025$ ), with drugs abuse behavior. Good communication among family members able to providing protection to child in order to avoid from drugs abuse. Good perception about drugs, stay with complete parents and in harmony has correlation to drugs abuse prevention.
\end{abstract}

Keywords: behavior, drugs, adolescence

Abstrak: Remaja merupakan masa peralihan dari masa anak ke dewasa yang mudah mengalami masalah psikologi dan perilaku, seperti kesulitan belajar, kecemasan, dan ketergantungan Napza. Anak sekolah merupakan kelompok yang rentan dalam melakukan perilaku penyalahgunaan Napza. Dampak penyalahgunaan Napza khususnya pemakaian jarum suntik secara bergantian berisiko tertular hepatitis B, C, dan HIV. Tujuan penelitian untuk mengetahui hubungan antara persepsi, jenis kelamin, status tempat tinggal, status orang tua dengan perilaku penyalahgunaaan Napza. Penelitian ini menggunakan desain analitik cross sectional dengan teknik simple random sampling. Populasi dalam penelitian adalah semua siswa-siswi yang berjumlah 155 orang, sampel sebanyak 50 orang. Analisis data menggunakan uji chi square. Hasil penelitian menunjukkan bahwa 83,7\% memiliki perilaku penyalahgunaan Napza dengan uji statistik menunjukkan bahwa tidak terdapat hubungan antara persepsi $(\rho$ Value $=0,826)$ dengan perilaku penyalahgunaan Napza, dan terdapat hubungan antara jenis kelamin ( $\rho$ Value $=0,001)$, terdapat hubungan status tempat tinggal ( $\rho$ Value $=0,001$ ), terdapat hubungan status orang tua ( $\rho$ Value $=0,025$ ), dengan perilaku penyalahgunaan Napza. Komunikasi yang baik antar anggota keluarga mampu memberikan proteksi pada anak agar terhindar dari penyalahgunaan Napza.

Persepsi yang baik tentang Napza, tinggal bersama orang tua yang utuh dan harmonis berhubungan dengan pencegahan penyalahgunaan Napza.

Kata kunci: Perilaku, Napza, Remaja

\section{PENDAHULUAN}

Peredaran Napza (Narkotika, Alkohol, Psikotropika, Zat Aditif lainnya) pada masyarakat masyarakat Indonesia terasa sangat memprihatinkan. Peredaran Napza sampai ke segala lapisan masyarakat, dari yang berstatus sosial tinggi sampai rendah, dari yang usia belasan tahun sampai usia puluhan tahun, dari yang siswa sekolah dasar sampai mahasiswa yang ada di perguruan tinggi, dari anak jalanan sampai anak anak yang setia dengan keluarga, tidak peduli 
putra atau putri, pria atau wanita yang ada di kota maupun di desa (BNN, 2016).

Studi yang dilakukan diseluruh dunia sesuai data United Nation Office on Drugs And Crime (2012), menunjukkan bahwa terdapat kurang dari $10 \%$ dari penduduk pada usia remaja umumnya menggunakan Napza. Berdasarkan data Badan narkotika nasional (BNN), pengguna narkoba mencapai $2,56 \%$ pada tahun 2013 dengan rentang usia 10-59 tahun. Menurut data BNN tahun 2015 diperoleh data dari 4,9 juta pengguna narkoba di Indonesia, 400 ribu diantaranya berada di Jawa Timur dengan status peringkat pertama sebagai provinsi dengan jumlah pengguna narkoba terbanyak di Indonesia. Penyalahgunaan narkotika di Sidoarjo tahun 2016 makin memprihatinkan bahkan pengguna tersebut lebih didominasi oleh kalangan remaja yaitu sebanyak $70 \%$.

Faktor - faktor penyebab penyalahgunaan NAPZA yang pertama berasal dari faktor individu seperti pengetahuan, sikap, kepribadian, jenis kelamin, usia, dorongan kenikmatan, perasaan ingin tahu, dan untuk memecahkan persoalan yang sedang dihadapi. Faktor kedua berasal dari lingkungannya seperti pekerjaan, ketidakharmonisan keluarga, status ekonomi, dan kelompok teman sebaya (Badri M, 2013 dalam Sholihah, 2013).

Menurut Hawari (2009), dampak penyalahgunaan Napza khususnya pemakaian jarum suntik secara bergantian berisiko tertular hepatitis B, C, dan HIV. Upaya meminimalkan penyalahgunaan Napza pada remaja yang paling efektif yang bisa dilakukan oleh tenaga kesehatan adalah pemberian pendidikan kesehatan terutama tentang Napza (Sumiati, et all, 2009). Tujuan penelitian ini adalah untuk mengetahui hubungan antara persepsi, jenis kelamin, status tempat tinggal, status orang tua dengan perilaku penyalahgunaaan Napza pada kelas XI di SMK Darul Huda Sidoarjo.

\section{BAHAN DAN METODE}

Penelitian ini menggunakan rancangan analitik cross sectional. Populasi dalam penelitian ini adalah semua siswa-siswi kelas XI di SMK Darul Huda Sidoarjo yang berjumlah 155 orang. Pengambilan sampel menggunakan teknik simple random sampling berjumlah 50 orang. Variabel independen dalam penelitian ini adalah persepsi, jenis kelamin, status tempat tinggal, status orang tua. Variabel dependen adalah perilaku penyalahgunaan Napza. Instrumen penelitian menggunakan kuesioner.

Pengumpulan data dilakukan pada Juni sampai Juli 2017 diawali dengan pengurusan perijinan sesuai dengan prosedur yang telah ditetapkan. Selanjutnya calon responden diberikan informasi terkait penelitian yang akan dilakukan dan responden yang bersedia dilakukan penelitian menandatangani lembar persetujuan menjadi responden (informed consent). Setelah data terkumpul kemudian dilakukan uji statistik $C h i$ Square.

\section{HASIL}

1) Usia

Tabel 1 Distribusi Responden Berdasarkan Usia

\begin{tabular}{|c|c|c|c|}
\hline Variabel & Mean & $\begin{array}{c}\text { Standar } \\
\text { Deviasi }\end{array}$ & $\begin{array}{c}\text { Nilai } \\
\text { Mak-Min }\end{array}$ \\
\hline Umur & 16 & .621 & $15-16$ \\
\hline \multicolumn{2}{|c|}{ Berdasarkan tabel 1 menunjukkan }
\end{tabular}
bahwa rata-rata usia responden 16 tahun, standar deviasi 0,621 tahun dan usia terendah responden 14 tahun dan usia tertua responden 17 tahun.

\section{2) Jenis Kelamin}

Tabel 2 Distribusi Responden Berdasarkan Usia

\begin{tabular}{|c|c|c|c|}
\hline No. & $\begin{array}{c}\text { Jenis } \\
\text { Kelamin }\end{array}$ & Jumlah (n) & $\begin{array}{c}\text { Persenta } \\
\text { se (\%) }\end{array}$ \\
\hline
\end{tabular}




\begin{tabular}{|c|c|c|c|}
\hline 1 & Laki-laki & 46 & 93,9 \\
\hline 2 & Perempuan & 3 & 6,1 \\
\hline & Total & 49 & 100 \\
\hline
\end{tabular}

Tabel diatas menunjukan bahwa, jenis kelamin terbanyak yaitu laki-laki sebanyak 46 responden $(93,9 \%)$.

\section{3) Persepsi}

Tabel 3 Distribusi Responden berdasarkan Persepsi

\begin{tabular}{|c|c|c|c|}
\hline No. & Persepsi & $\begin{array}{c}\text { Jumlah } \\
\text { (n) }\end{array}$ & $\begin{array}{c}\text { Persen } \\
\text { tase } \\
(\%)\end{array}$ \\
\hline 1 & Kurang & 21 & 42,9 \\
\hline 2 & Cukup & 28 & 57,1 \\
\hline & Total & 49 & 100 \\
\hline
\end{tabular}

Tabel 3 menunjukan bahwa dari 49 responden yang mempunyai persepsi kurang tentang Napza sebanyak 21 responden $(42,9 \%)$ dan persepsi cukup tentang Napza sebanyak 28 responden $(57,1 \%)$.

4) Status Tempat Tinggal

Tabel 4 Distribusi Responden berdasarkan Tempat Tinggal

\begin{tabular}{|c|c|c|c|}
\hline No. & $\begin{array}{c}\text { Tempat } \\
\text { Tinggal }\end{array}$ & $\begin{array}{c}\text { Jumlah } \\
(\mathrm{n})\end{array}$ & $\begin{array}{c}\text { Persentase } \\
(\%)\end{array}$ \\
\hline 1 & Kost & 27 & 55,1 \\
\hline 2 & Dgn Ortu & 22 & 44,9 \\
\hline & Total & 49 & 100 \\
\hline
\end{tabular}

Berdasarkan tabel 4 menunjukan bahwa dari 49 responden yang tinggal dengan selain orang tua/ kost sebanyak 27 responden $(55,1 \%)$.

\section{5) Status Orangtua}

Tabel 5 Distribusi Responden berdasarkan Status Orangtua

\begin{tabular}{|c|c|c|c|}
\hline No. & $\begin{array}{c}\text { Status } \\
\text { Ortu }\end{array}$ & $\begin{array}{c}\text { Jumlah } \\
(\mathrm{n})\end{array}$ & $\begin{array}{c}\text { Persentase } \\
(\%)\end{array}$ \\
\hline 1 & $\begin{array}{c}\text { Broken } \\
\text { Home }\end{array}$ & 28 & 57,1 \\
\hline 2 & Harmonis & 21 & 42,9 \\
\hline & Total & 49 & 100 \\
\hline
\end{tabular}

Berdasarkan tabel 5 menunjukan bahwa dari 49 responden yang mempunyai status orang tua broken home sebanyak 28 responden $(57,1 \%)$ dan status orang tua harmonis sedang sebanyak 21 responden $(42,9 \%)$.

6) Hubungan Jenis Kelamin dengan Perilaku Penyalahgunaan Napza

Tabel 6 Hubungan Jenis Kelamin dengan Perilaku Penyalahgunaan Napza

\begin{tabular}{|c|c|c|c|c|c|c|c|c|}
\hline \multirow{3}{*}{ No } & \multirow{3}{*}{ Jenis Kelamin } & \multicolumn{4}{|c|}{ Perilaku Penyalahgunaan } & \multirow{2}{*}{\multicolumn{2}{|c|}{ Jumlah }} & \multirow[t]{2}{*}{$\rho$ Value } \\
\hline & & \multicolumn{2}{|c|}{$\mathrm{Ya}$} & \multicolumn{2}{|c|}{ Tidak } & & & \\
\hline & & $\mathrm{n}$ & $\%$ & $\mathrm{n}$ & $\%$ & $\mathrm{n}$ & $\%$ & \\
\hline 1 & Laki-laki & 40 & 87 & 6 & 13 & 46 & 100 & \\
\hline 2 & Perempuan & 1 & 33,3 & 2 & 66,7 & 3 & & 0,001 \\
\hline & Total & 41 & 83,7 & 8 & 32,7 & 49 & 100 & \\
\hline
\end{tabular}


Berdasarkan hasil uji statistik dengan chi square diperoleh $\rho$ Value $=0,001$, dapat dimaknai bahwa ada hubungan jenis kelamin dengan

Tabel 7 Hubungan Persepsi dengan Perilaku Penyalahgunaan Napza

\begin{tabular}{|c|c|c|c|c|c|c|c|c|}
\hline \multirow{3}{*}{ No } & \multirow{3}{*}{$\begin{array}{c}\text { Persepsi } \\
\text { tentang Napza }\end{array}$} & \multicolumn{4}{|c|}{ Perilaku Penyalahgunaan } & \multirow{2}{*}{\multicolumn{2}{|c|}{ Jumlah }} & \multirow{2}{*}{$\rho$ Value } \\
\hline & & \multicolumn{2}{|c|}{$\mathrm{Ya}$} & \multicolumn{2}{|c|}{ Tidak } & & & \\
\hline & & $\mathrm{n}$ & $\%$ & $\mathrm{n}$ & $\%$ & $\mathrm{n}$ & $\%$ & \multirow{4}{*}{0,826} \\
\hline 1 & Kurang & 15 & 71,4 & 6 & 28,6 & 21 & 100 & \\
\hline 2 & Cukup & 18 & 64,3 & 10 & 35,7 & 28 & 100 & \\
\hline & Total & 33 & 67,3 & 16 & 32,7 & 49 & 100 & \\
\hline
\end{tabular}

Berdasarkan hasil uji statistik dengan chi square diperoleh $\rho$ Value $(0,826)$, dapat dimaknai bahwa tidak ada hubungan antara persepsi dengan perilaku penyalahgunaan Napza pada Kelas XI di SMK Darul Huda Sidoarjo.

\section{7) Hubungan Persepsi dengan Perilaku Penyalahgunaan Napza}

\section{8) Hubungan Status Tempat Tinggal dengan Perilaku Penyalahgunaan Napza}

Tabel 8 Hubungan Status Tempat Tinggal dengan Perilaku Penyalahgunaan

\begin{tabular}{|c|c|c|c|c|c|c|c|c|}
\hline \multirow{3}{*}{ No } & \multirow{3}{*}{$\begin{array}{c}\text { Status Tempat } \\
\text { Tinggal }\end{array}$} & \multicolumn{4}{|c|}{ Perilaku Penyalahgunaan } & \multirow{2}{*}{\multicolumn{2}{|c|}{ Jumlah }} & \multirow[t]{2}{*}{$\rho$ Value } \\
\hline & & \multicolumn{2}{|c|}{$\mathrm{Ya}$} & \multicolumn{2}{|c|}{ Tidak } & & & \\
\hline & & $\mathrm{n}$ & $\%$ & $\mathrm{n}$ & $\%$ & $\mathrm{n}$ & $\%$ & \multirow{4}{*}{0,001} \\
\hline 1 & Kost & 24 & 88,9 & 3 & 11,1 & 27 & 100 & \\
\hline 2 & Orang tua & 9 & 40,9 & 13 & 59,1 & 22 & 100 & \\
\hline & Total & 33 & 67,3 & 16 & 32,7 & 49 & 100 & \\
\hline
\end{tabular}

Berdasarkan hasil uji statistik dengan chi square diperoleh $\rho$ Value $=0,001$, dapat dimaknai bahwa ada hubungan status tempat tinggal dengan perilaku penyalahgunaan Napza pada Kelas XI di SMK Darul Huda Sidoarjo.

9) Hubungan Status Orang Tua dengan Perilaku Penyalahgunaan Napza

Tabel 9 Hubungan Status Orang Tua dengan Perilaku Penyalahgunaan

\begin{tabular}{|c|c|c|c|c|c|c|c|c|}
\hline \multirow{3}{*}{ No } & \multirow{3}{*}{$\begin{array}{c}\text { Status } \\
\text { Orang Tua }\end{array}$} & \multicolumn{4}{|c|}{ Perilaku Penyalahgunaan } & \multirow{2}{*}{\multicolumn{2}{|c|}{ Jumlah }} & \multirow[t]{3}{*}{$\rho$ Value } \\
\hline & & \multicolumn{2}{|c|}{$\mathrm{Ya}$} & \multicolumn{2}{|c|}{ Tidak } & & & \\
\hline & & $\mathrm{n}$ & $\%$ & $\mathrm{n}$ & $\%$ & $\mathrm{n}$ & $\%$ & \\
\hline 1 & Broken home & 23 & 82,1 & 5 & 17,9 & 28 & 100 & \multirow[t]{3}{*}{0,025} \\
\hline 2 & Harmonis & 10 & 47,6 & 11 & 52,4 & 21 & 100 & \\
\hline & Total & 33 & 67,3 & 16 & 32,7 & 49 & 100 & \\
\hline
\end{tabular}


Berdasarkan hasil uji statistik dengan chi square diperoleh $\rho$ Value $=0,025$, dapat dimaknai bahwa ada hubungan antara status orang tua dengan perilaku penyalahgunaan Napza pada Kelas XI di SMK Darul Huda Sidoarjo.

\section{PEMBAHASAN}

1) Hubungan Jenis Kelamin tentang Napza dengan Perilaku Penyalahgunaan Napza

Perilaku penyalahgunaan Napza pada remaja ditinjau dari jenis kelamin. Remaja yang berjenis kelamin laki-laki dan perempuan memliki perbedaan yang signifikan. Berdasarkan hasil uji statistik dengan chi square diperoleh nilai $\rho$ Value $=$ 0,001 . Dengan tingkat kepercayaan $95 \%(\alpha=$ $0,05)$. Sesuai dengan dasar pengambilan keputusan penelitian hipotesis bahwa jika $\rho$ Value $(0,001)<0,05$ maka $\mathrm{H}_{0}$ ditolak atau $\mathrm{H}_{1}$ diterima sehingga dapat dimaknai bahwa ada hubungan jenis kelamin dengan perilaku penyalahgunaan Napza pada Kelas XI di SMK Darul Huda Sidoarjo. Selanjutnya dari uji keeratan hubungan di peroleh nilai phi $\varnothing$ sebesar 0,509 yang berarti hubungan antara jenis kelamin dengan perilaku penyalahgunaan Napza pada Kelas XI mempunyai kategori hubungan sedang.

Hasil ini sesuai dengan teori yang dikemukakan oleh Afandi, dkk (2009), faktor penyalahgunaan NAPZA salah satunya dipengaruhi oleh jenis kelamin. Hal senada diungkapkan pula oleh Ruminiati (2010) bahwa remaja laki-laki lebih ambisius dan memiliki tingkat agresi yang lebih tinggi dibandingkan dengan remaja perempuan. Afandi (2009) juga menegaskan bahwa jenis kelamin laki-laki lebih berisiko terhadap penyalahgunaan NAPZA. Diperkuat oleh pendapat yang dikemukakan oleh Kartono (2010) bahwa salah satu faktor yang memengaruhi kenakalan pada remaja adalah jenis kelamin. Hawari (2009) menyatakan bahwa pada masyarakat Jawa dan Sunda, dalam sudut pandang orangtua serta masyarakat umum menjadi hal yang wajar ketika anak laki-laki melakukan kesalahan dan kenakalan, berbeda dengan anak perempuan yang diharuskan untuk lebih banyak berdiam di dalam rumah dan tidak ditolerir untuk melakukan hal-hal seperti yang dilakukan oleh anak laki-laki seperti kenakalan. Menurut Erikson (Santrock, 2002), bahwa laki-laki dan perempuan memiliki kepribadian yang berbeda dimana hal tersebut dipengaruhi oleh struktur jenis kelamin.

Laki-laki lebih suka mengganggu dan agresif, sedangkan perempuan lebih inklusif dan pasif sehingga laki-laki lebih banyak mengalami permasalahan dengan lingkungan sosialnya. Dengan demikian maka hipotesis yang diajukan peneliti diterima.

2) Hubungan Persepsi tentang Napza dengan Perilaku Penyalahgunaan Napza

Persepsi adalah proses pengorganisasian, penginterpretasian terhadap rangsang yang diterima oleh organisme atau individu sehingga merupakan sesuatu yang berarti dan merupakan aktivitas yang integrated dalam diri individu (Bimo, 2001). Persepsi juga dapat diartikan sebagai proses diterimanya rangsang melalui pancaindra yang didahului oleh perhatian sehingga individu mampu mengetahui, mengartikan, dan menghayati tentang hal yang diamati, baik yang ada di luar maupun dalam diri individu (Sunaryo, 2004). Sedangkan menurut (Notoatmodjo, 2003), persepsi adalah mengenal dan memilih berbagai objek sehubungan tindakan yang akan diambil atau pengalaman yang dihasilkan melalui indera penglihatan, pendengaran, penciuman, dan sebagainya.

Berdasarkan hasil uji statistik dengan chi square diperoleh nilai Sesuai dengan dasar pengambilan keputusan penelitian hipotesis bahwa jika $\rho$ Value $(0,826)>0,05$ maka $\mathrm{H}_{0}$ diterima atau $\mathrm{H}_{1}$ ditolak sehingga dapat dimaknai bahwa tidak ada hubungan antara persepsi dengan perilaku 
penyalahgunaan Napza pada Kelas XI di SMK Darul Huda Sidoarjo.

Menurut penelitian Suwanto (2013), salah satu upaya pemberantasan narkoba melalui dna pendidikan. Institut pendidikan merupakan salah satu pihak yang berkewajiban dan bertanggung jawab dalam upaya pencegahan penyalahgunaan narkoba di kalangan remaja. Namun pada penelitian Rosdiana (2013) menyatakan bahwa tidak ada hubungan signifikan antara pengetahuan dengan sumber informasi yang diperoleh dengan nilai $\mathrm{p}=0,478(\rho>0,005)$.

Peneliti berpendapat bahwa sumber informasi yang mempengaruhi persepsi responden dikarenakan tidak adanya penghayatan dan rasa keingintahuan responden terhadap suatu informasi yang diterimanya.

3) Hubungan Status Tempat Tinggal dengan Perilaku Penyalahgunaan Napza

Perilaku penyalahgunaan Napza pada remaja ditinjau dari status tinggal. Remaja yang tinggal bersama orangtua, bersama sanak saudara maupun tinggal di kost atau kontrak rumah sendiri memliki perbedaan yang signifikan. Berdasarkan hasil uji statistik dengan chi square diperoleh nilai $\rho$ Value $=0,001$. Dengan tingkat kepercayaan $95 \%(\alpha=0,05)$. Sesuai dengan dasar pengambilan keputusan penelitian hipotesis bahwa jika $\rho$ Value $(0,001)<$ 0,05 maka $\mathrm{H}_{0}$ ditolak atau $\mathrm{H}_{1}$ diterima sehingga dapat dimaknai bahwa ada hubungan status tempat tinggal dengan perilaku penyalahgunaan Napza .

Hasil analisa ini sesuai dengan pendapat yang dinyatakan oleh Afandi, dkk (2009) yang melaporkan bahwa remaja/ siswa yang tidak tinggal bersama orang tua (kost/ sewa/ saudara) lebih berisiko untuk terjerumus dalam penyalahgunaan Napza. Hal serupa diungkapkan oleh Carlson, 2006 (dalam Papalia, 2014) bahwa remaja yang tinggal bersama orang tua yang utuh cenderung memiliki masalah perilaku yang lebih sedikit daripada remaja dengan status tinggal orang tua tunggal, keluarga tanpa pernikahan, atau keluarga tiri.

Remaja yang tinggal bersama orangtua, sanak saudara, atau kost/ sewa sama-sama memiliki risiko penyalahgunaan Napza. Walaupun banyak teori dan penelitian lain yang menyebutkan bahwa remaja yang tinggal tidak bersama orangtua lebih cenderung melakukan kenakalan dan penyalahgunaan Napza akan tetapi perlu dilihat bahwa keluarga yang memiliki intensitas komunikasi yang intim akan berpengaruh pada pembentukan kepribadian dan karakter anak.

4) Hubungan Status Orang Tua dengan Perilaku Penyalahgunaan Napza

Serupa dengan penyebab penyalahgunaan Napza pada remaja dengan status tinggal, penyalahgunaan Napza pada remaja dengan status orangtua utuh maupun tunggal juga memiliki perbedaan yang signifikan. Berdasarkan hasil uji statistik dengan chi square diperoleh nilai $\rho$ Value $=0,025$. Dengan tingkat kepercayaan $95 \%$ $(\alpha=0,05)$. Sesuai dengan dasar pengambilan keputusan penelitian hipotesis bahwa jika $\rho$ Value $(0,025)<0,05$ maka $\mathrm{H}_{0}$ ditolak atau $\mathrm{H}_{1}$ diterima sehingga dapat dimaknai bahwa ada hubungan antara status orang tua dengan perilaku penyalahgunaan Napza. Hal ini dapat diartikan bahwa ada perbedaan risiko penyalahgunaan Napza pada subjek dengan orangtua utuh maupun dengan status orangtua tunggal/ broken home.

Hasil analisa ini sesuai dengan teori yang dicetuskan oleh Hawari (2009) yang menyebutkan bahwa salah satu faktor remaja melakukan penyalahgunaan Napza adalah keutuhan keluarga dimana remaja dengan status orangtua tunggal baik karena bercerai maupun karena meninggal lebih cenderung melakukan penyalahgunaan Napza itu sendiri. Grudem, (1996) dan Sun, (2001) dalam Papalia, (2014) menyebutkan bahwa remaja dengan status orangtua yang bercerai 
menunjukkan masalah multidimensional seperti masalah akademis, psikologis, dan permasalahan perilaku menyimpang lainya. Silalahi \& Santoso (2000) juga menyebutkan bahwa anak dengan korban perceraian menimbulkan permasalahan kurang percaya diri, kurang sukses di pendidikan dan pergaulan, pemarah, suka mencela diri sendiri, selalu menyembunyikan perasaannya dan mudah frustasi. Pada penelitian ini dapat dinyatakan bahwa status orangtua tidak dapat menentukan seseorang lebih berisiko terhadap penyalahgunaan Napza, hasil rerata menunjukkan bahwa remaja dengan status orangtua tunggal memiliki risiko yang lebih rendah sehingga orangtua tunggal juga mampu memberikan pengasuhan yang baik sehingga dapat menghindarkan remaja dari risiko penyalahgunaan Napza.

Secara umum, orangtua tunggal mengalami hal-hal yang negatif dan dipandang oleh lingkungan sosialnya sebagai hal yang negatif pula sehingga seringkali memberi dampak yang kurang baik pada perkembangan anak. Menurut Rimm (dalam Nurjanah, 2015) orangtua tunggal juga memiliki kesempatan untuk membentuk kondisi pengasuhan yang baik dan ideal dengan syarat (1) memiliki karir yang jelas (2) terdapat orangtua kedua untuk mendukung orangtua tunggal (3) tersedia pengasuhan anak yang teratur dan dapat diandalkan (4) orangtua diharuskan mampu dalam mempertahankan hidup sosial yang positif.

Hawari (2009) menyebutkan bahwa kesibukan orangtua dan hubungan interpersonal antar anggota keluarga sebagai salah satu faktor yang berkontribusi pada risiko penyalahgunaan Napza pada remaja. Artinya, walaupun remaja dengan pengasuhan orangtua tunggal akan tetapi memiliki hubungan serta komunikasi yang baik antar anggotanya maka hal tersebut mampu memberikan proteksi pada anak untuk terhindar dari penyalahgunaan Napza.

Kesibukan orangtua juga ikut berpengaruh dan sebaiknya menjadi perhatian, remaja dengan kesibukan orangtua yang padat akan tetapi mampu menyediakan waktu dan memiliki komunikasi yang positif seperti yang dijelaskan di atas maka penyalahgunaan Napza pada remaja dapat ditekan. Hal demikian berlaku sebaliknya, pada remaja yang memiliki orangtua utuh akan tetapi anak tidak mendapatkan perhatian yang dibutuhkan karena kesibukan orangtua dan secara otomatis tidak terjalinnya komunikasi yang baik di antara anggota keluarga, hal tersebut dapat memicu anak untuk melakukan penyalahgunaan Napza.

\section{KESIMPULAN DAN SARAN}

Sebagian besar senyawa DA menghasilkan efek multipel yang mengakibatkan penurunan melanisasi.

\section{Kesimpulan}

1) Rata - rata usia responden 16 tahun.

2) Jenis Kelamin terbanyak adalah laki-laki.

3) Ada hubungan antara jenis kelamin, status tempat tinggal dan status orangtua dengan perilaku penyalahgunaan Napza

4) Tidak ada antara hubungan antara persepsi dengan perilaku penyalahgunaan Napza.

\section{Saran}

Diharapkan kepada tenaga kesehatan terutama yang berada di fasilitas kesehatan terdekat dengan sekolah dapat memberikan tindakan preventif berupa health education kepada remaja terutama mengenai Napza beserta dampak penyalahgunaan Napza serta memberikan fasilitas kesehatan yang memadai sehingga remaja mudah mengakses informasi terkait Napza. 


\section{DAFTAR PUSTAKA}

Agustiani, H. (2006). Psikologi Perkembangan Pendekatan Ekologi Kaitannya dengan Konsep Diri dan Penyesuaian Diri pada Remaja. Bandung : PT. Refika Aditama.

Arikunto, S. (2006) Prosedur Penelitian Suatu Pendekatan Praktek.Rineka Cipta. Jakarta.

Azwar, S. (2009). Sikap Manusia Teori dan Pengukurannya Edisi ke 2. Yogyakarta : Pustaka Belajar.

Bungin, Burhan. (2007). Metode Penelitian Kualitatif, Rajawali Pers, Jakarta.

BNN, 2016. Kumpulan Hasil Penelitian Badan Narkotika Nasional pada tahun 2016. Jakarta Timur : Badan Narkotika Nasional Republik Indonesia

Departemen Kesehatan (2003). Pelayanan Kesehatan Peduli Remaja (PKPR). Jakarta : Direktorat Kesehatan Keluarga.

Frihartine, 2013. Factor-Faktor Yang Mempengaruhi Perilaku Merokok Pada Siswa Laki-Laki Disekolah Menengah Atas Negeri 1 Banda Aceh Tahun 2013. Program Studi D-IV Kebidanan Sekolah Tinggi Ilmu Kesehatan U'budiyah Banda Aceh.

Hawari, D. (2008). Terapi (Detoksifikasi) Narkobal NAZA\&HIV/ AIDS. Jakarta : Balai Penerbit FKUI.

(2009). Penyalahgunaan \& Ketergantungan NAZA. Jakarta : Balai Penerbit FKUI

Kartono, Kartini. 2010. Kenakalan Remaja. Jakarta. PT. Raja Grafindo Persada. Rajawali Pers. 